\title{
A Special Service of Guidance and Counseling Management to Reduce the Students' Glossophobia Level
}

\author{
Titin Indah Pratiwi, Bambang Suratman, Yatim Riyanto, Pradita Arisgi Werhadiantiwi \\ Universitas Negeri \\ Surabaya, Indonesia \\ titinindahpratiwi@unesa.ac.id
}

\begin{abstract}
Many students are afraid to talk in public. The observation social science students of a Public High School (SMA) showed that $77.42 \%$ students were afraid to talk in public (glossophobia). This paper presents result of a research on a treatment using a self-instruction technique.

The data of this research were collected by filing glossophobia questionnaire, in which the data were analyzed by nonparametric technique with Wilcoxon test level. The results of analyses showed that with $n=6$, we found $T_{\text {able }}=-1$ in which it was lower than $\alpha$ of $5 \%=0$. Scoring results showed that there was a reduction of mean score of pre-test and post-test from 162.17 to 150.33 . Therefore $\mathrm{HO}$ was rejected and $\mathrm{Ha}$ was accepted. The treatment using a group counseling by selfinstruction technique can reduce the level of glossophobia of students.
\end{abstract}

Keywords-glossophobia; group counseling; self-instruction technique

\section{INTRODUCTION}

In daily life, people are facing many things related to others. Students will meet other or crowd during presentation, resting in a canteen, or joint an extracurricular activities, and many other activities. Sometimes they need to talk to individual or to a group of people. However, some people has problems when they have to face crowd. This symptoms is called glossophobia. Glossophobia is one of social anxiety disorder in which a person who suffer this type of disorder fear to talk in public. The anxiety itself is uneasiness feeling or fearfulness which coming to threat individuals without being known [1] (Boonsuchat, 2015). The level of anxiousness is different on each person. The person with glossophobia mostly has self-focused attention problem. As reported by some authors (see [2] Deiters ebt.al, 2013), an individual with high social anxious individuals (HSA) was reported significantly more self-focused attention than low social anxious individuals (LSA) when talking to a stranger, giving a speech, or being at the center of attention. They concluded that individuals with high in speech anxiety directed their attention more inwards compared to low anxious individuals during their speech task. However, during the actual speech task, the relative bias toward interoceptive cues could not detected anymore. Nevertheless, high anxious individuals tend to be more alert to both, internal and external attentional cues compared to low speech anxious individuals. They found, both high and low speech anxious individuals give more attention of their attentional resources externally.

In this paper, a research related to glossophobia on high school students is presented. Some facts indicate that many high school students suffer from glossophobia, in which the symptoms are increased heart rate, dry mouth, trembling voice due to stress, stiff neck, out of breath, and forget what to be spoken, when the students are asked to talk in front of the class. The students are not introvert. Actually, they like to gather with friends. However, when they are asked to talk in public, to express their ideas, then they feel afraid. The fear of talking in public is categorized as a social phobia, that has symptoms: ashamed, sweated, high heart rate, trembling, dry mouth, increased body temperature, and no-fluent talking. The fear of talking in public is something that involve fear to be judged or evaluated by others. Therefore, according to Bippus and Daly (1999) in [1][2] the common reasons for speaking anxiety are as follows: fear of abasement, to prepare badly, lack of confidence related to the physical appearance, the fear of being criticized by the audience when there is no perfect performance, anxiety or low self-esteem, indifference of the audience, the speaker to be inexperienced, the fear of making a mistake, the fear of failures fear is commonly following by a significant physical reactions and emotion that can disturb the ability of an individual giving speech or presentation. The reactions are worry, nervous, trembling, sweated, and dizzy. Many experts predict that about $75 \%$ of population has different level of fear to talk in public.

The subject of this research are SMA's students. The results of discussion with the counseling teacher of the SMA concluded that many student are fear to talk in public. There were 24 students out of 31 students $(77.42 \%)$ suffer glossophobia.

The students who have high score of suffering glossophobia were selected. The students were then treated using the self-instruction technique such that their irrational negative thinking changes to the positive one such that their 
behavior changes to be positive. In the application of selfinstruction technique, the students are taught to strengthen their own to control the faced situation when glossophobia arise. In practice, students with glossophobia are gathered in a group and they are treated by a group counseling. Wiener in [4] stated that the purpose of counseling is as a therapeutic medium for clients since it can improve self-understanding and it is useful to change an individual behavior.

A group counseling will be effective to handle problems of several students with the same problems, in this research, they are students with glossophobia. This method has been used by many authors in treating various anxiety problems [5]; [6]; [7]; [8]; [9]; [10]; [11]). Therefore, this research focuses on the implementation of a self-instruction (SI) technique [12] to reduce the glossophobia level of high school students of The SMA. SI is defined as (see [13] Smith, et.al, 2015) "the use of self-talk, printed instructions, or other materials that are used by the person alone rather than provided by the teacher. These instructions 'set the occasion' (i.e., are a discriminative stimulus) for the target behavior. Self-instructional materials like pictorial task analyses, videos, and auditory prompts, reduce the need for adult instruction while still providing support for completing multi-step tasks". This technique was used by [3] for treating primary school students with dyslexia. They found that self-instruction technique improved reading performance of the students with dyslexia. Moreover, their anxiety also reduced significantly since their anxiety was caused by their problems in reading. In this research, the students were treated by this technique in a group counseling.

\section{METHOD}

This research uses a quantitative approach by an experimental method to investigate the influence of a specific treatment to the subjects in a controlled condition [4]; [5]; [6] The research design is pre-experimental design with pre-test dan post-test one group design model. The similar methods were used by [7] Haddadian et.al (2012) and [8] Choure et al (2015) in treating children with Dyslexia and individuals during cardiac rehabilitation, respectively. Both treatments showed good results.

The samples of this research is students of the SMA that are chosen using nonprobability sampling technique, purposive sampling type (samples are chosen based on specific characteristic and purpose). 6 students were chosen as an experiment group. However, to make the discussion in the group more dynamic than 2 more subjects, who have medium score of glossophobia, are added. Since the focus of this research is for high level of glossophobia score, then two added subjects will not be included in the analysis. The method of Wilcoxon's Rank Sum Test, which is an improved method of the signed test, is utilized. The steps of doing the technique are (i) identification of negative self-belief; (ii) practice of positive talking to reduce self-negative statement; (iii) practice self-instruction technique to apply desired behavior; and (iv) determine self-reinforcement if they are success to face the negative situation.

\section{RESULT AND DISCUSSION}

The results of pre-test, it is found that 6 students get high score of glossophobia and they are chosen as the subject of the group experiment [19]. The results of questionnaires are shown in Table 1. The subjects met with the researchers for 6 times. During the meeting in the counseling group, the subjects are treated by the self-instruction technique. After 6 meetings, the subjects are given a post-test. The results of pretest and post-test are presented in Table 2.

The pre-test and post-test scores are then analyzed by a non-parametric statistical test by using Wilcoxon's Rank Sum Test. From Table 2, it is known that the positive rank $=15$ and the negative one $=-1$. Based of the Wilcoxon T-test, the smallest $\mathrm{T}$ is taken, therefore, $\mathrm{T}_{\text {-calculated }}=-1$. The mean of pretest is 162.17 while the mean of post-test is 150.33 with the difference of 11.84 score. From the table of critical value of $\mathrm{T}$ of the Wilcoxon's Rank sum Tes with significant number of $5 \%$ and $\mathrm{N}=6$, it is found that $\mathrm{T}_{\text {-table }}=0$. T-calculated is smaller than $\mathrm{T}_{\text {-table }}(-1<0)$, then $\mathrm{H} 0$ is rejected and $\mathrm{Ha}$ is accepted. It means, the hypothesis that there is difference scores of students with glossophobia before and after provided with group counseling by the self-instruction technique to the students of the SMA is accepted. It is found that the scores of 5 students decreased significantly. However, the score of 1 student increases 1 point, it is because the student was not focus during the explanation session of the counselor. The researcher has given personal guidance to the student (ZS) and made a behavior contract to the student for having commitment to change his behavior.

TABLE 1 RESULTS OF GLOSSOPHOBIA TEST WITH HIGH SCORES

\begin{tabular}{|l|l|l|l|}
\hline No & $\begin{array}{l}\text { Initial of } \\
\text { subjects }\end{array}$ & Score & Remarks \\
\hline 1 & MC & 171 & High \\
\hline 2 & DF & 168 & High \\
\hline 3 & SA & 160 & High \\
\hline 4 & LM & 159 & High \\
\hline 5 & ZS & 157 & High \\
\hline 6 & MR & 158 & High \\
\hline
\end{tabular}

TABEL 2 RESULTS OF ANALYSIS OF PRE-TEST AND POST-TEST

\begin{tabular}{|c|c|c|c|c|c|c|c|}
\hline \multirow[t]{2}{*}{ No } & \multirow{2}{*}{\begin{tabular}{|c|}
$\begin{array}{c}\text { Initial } \\
\text { of } \\
\text { subjects }\end{array}$ \\
(Xi)
\end{tabular}} & \multirow{2}{*}{$\begin{array}{c}\begin{array}{c}\text { pre- } \\
\text { test } \\
\text { score }\end{array} \\
\text { (Yi) }\end{array}$} & \multirow{2}{*}{\begin{tabular}{|c|}
$\begin{array}{c}\text { post- } \\
\text { test } \\
\text { score }\end{array}$ \\
(Xi-Yi)
\end{tabular}} & \multirow[t]{2}{*}{ Difference } & \multirow[t]{2}{*}{ Rank } & \multicolumn{2}{|c|}{ Rank sign } \\
\hline & & & & & & Positive & Negative \\
\hline 1 & $\mathrm{MC}$ & 171 & 156 & 15 & 5 & +5 & 0 \\
\hline 2 & $\mathrm{DF}$ & 168 & 150 & 18 & 4 & +4 & 0 \\
\hline 3 & SA & 160 & 143 & 17 & 3 & +3 & 0 \\
\hline 4 & LM & 159 & 145 & 14 & 1 & +1 & 0 \\
\hline 5 & $\mathrm{ZS}$ & 157 & 159 & 2 & 6 & 0 & -1 \\
\hline 6 & MR & 158 & 146 & 12 & 2 & +2 & 0 \\
\hline \multicolumn{2}{|c|}{ Mean } & 162.17 & 150.33 & \multicolumn{2}{|l|}{ Sum } & +15 & -1 \\
\hline
\end{tabular}

The analysis of the research results confirm that majority of subject have been influenced after treated by group counseling using the self-instruction technique. There is changing of glossophobia behavior includes its symptoms which coming from negative cognitive of irrational thinking to positive thinking that can improve the capability of subject to talk in public. Individually, the decrease of glossophobia score 
of students in the experiment group varies (except the ZS subject who has increased score). The score of $\mathrm{MC}$ is decreasing from 171 (high) to 156 (medium). The score of DF is decreasing from 168 (high) to 150 (medium). The score of SA is decreasing from 160 (high) to 147 (medium). The score of LM is decreasing from 159 (high) to 145 (medium). The score of ZS is increasing from 157 (high) to 159 (high). The score of MR is decreasing from 158 (high) to 146 (medium). There are some changing of behavior of students during their speech in front of their friends. The researcher observed and asked questions to student after the group counseling practices to investigate whether there was an improvement to be better of the students' behavior during they speak in front of their friends. It was found that the students did not feel much trembling, and more importantly the subjects changed from negative to positive thinking and believes that everybody has potential such that the symptoms of glossophobia was reducing. In the self-instruction technique the students are taught to control their feeling when the glossophobia symptom coming up. In general, the subjects have been aware of the usefulness of the self-instruction and they can use it anytime they have problem during speaking in public. The selfinstruction technique is one of techniques of cognitive behavioral therapy, which was developed by Meinchebum, that is used for reducing glossophobia due to negative thinking especially due to irrational thinking.

The results of this research is confirmed to the previous research by [9] with the title of "the Use of a Group Counseling by Reframing Strategy and Self Modelling to reduce the anxiety of speaking in public". This technique can be successfully reduce the anxiety of subjects talking in public. Reframing is a change of view of an individual from negative to the positive one. The change of negative thinking to the positive one can reduce anxiety during speaking in public.

Another previous research [10]] has been conducted on SMA's Students in Gresik-East Java". This technique has been proven to reduce anxiety of students talking in public. The Group Counseling of Rational Emotive (RE) can reduce glossophobia of students of the SMA.

This research has a contribution in development of science. Therefore, from the discussion above, it can be concluded that the use of a group counseling using self-instruction technique is able to reduce glossophobia level of students.

\section{CONCLUSION}

Based on the research analysis, it can be concluded that there is a significant change of scores of glossophobia of students before and after the group counseling implementation using a self-instruction technique. Wilcoxon Rank Sum Test showed that the positive signed rank $=15$ while the negative signed rank $=-1$. The mean of score of pre-test is 162.17 while the mean of post-test score is 150.33 . The reduction of score is 11.84. Based on the Wilcoxon $\mathrm{T}$, the smallest $\mathrm{T}$ value is chosen then $\mathrm{T}_{\text {-calculated }}=-1$. From the table of critical value of $\mathrm{T}$ of the Wilcoxon's Rank Sum Test with significant number of $5 \%$ and $\mathrm{N}=6$, it is found that $\mathrm{T}_{\text {-table }}=0 . \mathrm{T}_{\text {-calculated }}$ is smaller than $\mathrm{T}$-table $(-1<0)$, then $\mathrm{H}_{0}$ is rejected and $\mathrm{H}_{\mathrm{a}}$ is accepted.

\section{SUGGESTIONS}

Some suggestions can be proposed as follows:

1. For school counselor

a. School counselor can apply the group counseling by using self-instruction technique to reduce glossophobia of students

b. Group counseling need to be conducted in an appropriate time frame to obtain better results in reducing glossophobia of students

c. Since there are many students have problems with glossophobia, counselors must try to prevent students from it by pushing students to explore them self as much as possible for finding their potential and the counselor try to treat students with glossophobia as soon as possible in the best way.

\section{For other researchers}

a. This research can be used for starting point in conducting the similar research in treating students with glossophobia symptoms.

b. It needs more time in doing the treatment using this technique for a better results.

c. Researcher need to be close to the students for applying this technique to obtain better reduction in glossophobia of students.

\section{References}

[1] J. Boonsuchat, "Group Counseling for Reducing the Anxiety in Parents of Children with Autism," Procedia-Social Behav. Sci., vol. 197, pp. 640644, 2015.

[2] D. D. Deiters, S. Stevens, C. Hermann, and A. L. Gerlach, "Internal and external attention in speech anxiety," J. Behav. Ther. Exp. Psychiatry, vol. 44, no. 2, pp. 143-149, 2013.

[3] H. Yaman and T. Demirtaş, "A Research On Speech Anxiety of the Second Grade Primary School Students," Procedia-Social Behav. Sci., vol. 122, pp. 536-542, 2014.

[4] P. Latipun, "Konseling.” Malang: UMM Press, 2008.

[5] R. L. Gibson, Y. Santoso, and M. H. Mitchell, Bimbingan dan konseling. Pustaka Pelajar, 2010.

[6] E. Zarei, A. A. S. Fini, and H. khajehzadeh Fini, “A comparison of Effect of group counselling methods, behavioural, cognitive and cognitivebehavioural to reduce students Test anxiety in the University of Hormozgan," Procedia-Social Behav. Sci., vol. 5, pp. 2256-2261, 2010.

[7] F. Gültekin, Z. Erkan, and S. Tüzüntürk, "The effect of group counseling practices on trust building among counseling trainees: From the perspective of social network analysis," Procedia-Social Behav. Sci., vol. 15, pp. 2415-2420, 2011.

[8] N. Choure, H. K. Chandrawanshi, M. S. Rajput, S. Sehgal, M. E. Patliya, and P. D. Sarkar, "The effectiveness of self instructional module on cardiac rehabilitation,” Int. J. Nurs. Sci., vol. 2, no. 3, pp. 317-323, 2015.

[9] D. Ratnasari, "Penggunaan Konseling Kelompok dengan Kombinasi Strategi Refreming dan Self Modeling Untuk Menurunkan Tingkat Kecemasan Berbicara di Depan Umum. Skripsi." Surabaya: UNESA. Tidak diterbitkan, 2012.

[10]P. ARISGI W, "Penerapan Konseling Kelompok dengan Teknik Self Instruction untuk Mengurangi Tingkat Glossophobia pada Siswa Kelas XI IPS-1 Di SMA Negeri 1 Gedangan,” J. BK UNESA, vol. 4, no. 3, 2014. 